\title{
THE ROLE OF CORPORATE GOVERNANCE IN ENSURING ECONOMIC SECURITY OF ENTERPRISES IN THE CONSTRUCTION INDUSTRY
}

\author{
Iryna Mihus ${ }^{1}$, Vasyl Dmitrenko ${ }^{2}$ \\ ${ }^{I}$ Doctor of Science (Economics), professor, "KROK" University, Kyiv, Ukraine, e-mail: \\ irynamihus@gmail.com, ORCID: https://orcid.org/0000-0001-6939-9097 \\ ${ }^{2}$ Ph.D. (Economics), Professor, Cherkasy Institute of Fire Safety named after the Heroes of Chernobyl, \\ Cherkasy, Ukraine, e-mail: dmytrenkovi@ukr.net, ORCID : https://orcid.org/0000-0003-1860-418X
}

The formation of domestic entrepreneurship on a new civilizational basis, which provides for the integration of Ukraine into the world economic space, leads to intensification of the implementation of domestic companies principles and standards of corporate governance. The following facts testify in favor of the growing relevance of corporate governance for Ukrainian enterprises. First, in developing countries, the introduction of corporate governance is one of the most important prerequisites for public business. It provides for the systematization of general principles of enterprise management, a clear and transparent distribution between the main stakeholders (stakeholders) of authority and responsibility for increasing the value of the company. Secondly, the quality of corporate governance is becoming one of the most important factors that helps reduce the uncertainty of the environment of operation and development of companies by providing information transparency for all its stakeholders. Third, the implementation of transformational corporate governance projects in the company becomes an impetus for qualitative and large-scale changes in the management system, and therefore it is practically impossible without competent consulting assistance.

In the process of privatization and privatization of domestic enterprises in Ukraine there is a gradual formation of the institution of corporate governance. With the formation of large Ukrainian business, the intensification of corporatization processes, the spread of holding companies, the need for the formation and implementation of corporate governance standards has become significantly more relevant.

Despite the growing need to apply corporate principles of business management in joint stock companies, most such companies in Ukraine do not have de facto corporate governance or the level of its quality is considered low.

Today in the world there is a tendency to strengthen the foundations of the regulatory system of corporate relations, creating generally accepted principles (standards) that underlie effective corporate governance and can be applied in a wide range of legal, economic and political conditions. The emergence of generally accepted standards of corporate governance is primarily due to the growing attention to corporate governance in the context of globalization of financial markets, 
liberalization of capital movements. This is an attempt to establish generally accepted, transparent and understandable worldwide "rules of the game" in the financial market. The development of international standards of corporate governance is also society's response to global financial crises and due to the desire for stability of financial markets. After all, good corporate governance is a guarantee of investor confidence - both domestic and foreign - and contributes to the establishment of normal production and economic activities, job creation, payment of taxes to the budget, increase profitability and long-term production efficiency, increase stock value.

Thus, it can be argued that corporate governance reform has become an integral part of the modern world economy.

The modern development of corporate governance in Ukraine is characterized by the existence of a number of problems of a conceptual nature, the uncertainty in the interpretation of which significantly complicates the implementation of the strategy of national model of corporate governance.

Today there is no single definition of corporate governance in either foreign or domestic scientific literature. Different interpretations of the essence of this concept remain quite common, so it is necessary to consider and systematize different approaches to the definition of corporate governance [1].

Leading foreign economists Berle A. and Means G. are considered to be the founders of corporate governance [2]. A number of classics of economics - P. Drucker [3], J. Keins [4], A. Marshall [5-6], M. Porter [7], P. Samuelson [8], E. Chamberlyn [9] - provided this aspect of economics is important. Further, their research was developed in the works of such well-known foreign scientists as I. Akoff [10], J. Banquet [11], D. Lorsch, R. LaPorta [11], N. Minov \& R. Monks [1213], A. Radigin [14], B. Steward [15], W. Salmon [11], W. Shein [16] and others.

Some aspects of corporate governance and valuation are considered by domestic scientists in the study of the issue: improving the mechanism of corporate relations A. Voronkova [17], V. Yevtushevsky [18], G. Kozachenko [19]; building the organizational structure of corporate governance and management systems O. Kuzmin [20], H. Nazarova [21-22], Ye. Palyha [23]; evaluation of the effectiveness of corporate sector enterprises A. Achkasov [24], I. Blank [25], O. Vakulchik [26], G. Volynsky [27-29], O. Ivanilov [30], V. Lushkin [31], M. Chumachenko [32]; cost management of enterprises in terms of their adaptation to the transformation processes of the transition period O. Mendrulom [33, 34], R. Tianom [35]; system development of organizational and economic mechanism of corporate governance, creation of systems to support management decisions, investment analysis and mathematical research methods - V. Anin [36], A. Krushevsky [37-39], V. Onishchenko [40], O. Respected [41, 42], V. Torkatyuk 
[43-46], V. Fedorenko [47]; of corporate management of financial and construction groups in the investment process - S. Ushatsky [48-49], O. Fedosova [50]; of strategic management - V. Michels [51], A. Nalivaykom [52], O. Tishchenko [53], L. Shevchenko [54]; L. Shutenkom [55-57]; of corporate governance at the regional level - P. Bubenko [58], A. Golikov [59-60], M. Dolishni, G. Kovalevsky [61-63], V. Nikolaev [64], G. Onishchuk [65], V. Sergienko [66].

A comprehensive study of the works of foreign and domestic scientists has shown that almost all of them focus on the problems of creating and developing corporate relations. The issues of assessing their economic efficiency have receded into the background, despite the fact that traditional methods of assessing the economic efficiency of management are practically not suitable for joint stock companies. Thus, given that the phrase "corporate governance" has become international and widely used not only in Ukraine but also in countries with long traditions of market economy, CIS countries, Eastern Europe, relevant research on solving conceptual problems of corporate governance taking into account national characteristics formation of the corporate sector of the economy. Therefore, it is important to systematize and generalize modern approaches to the definition of corporate governance, taking into account national characteristics and the current state of the corporate sector.

The analysis of scientific works and the legal base allowed to systematize the approaches to the definition of corporate governance.

The approach, which involves the division of participants in corporate governance into the institution of owners and the institution of managers and taking into account their interests - is to protect the interests of a certain group of participants in corporate relations (investors) from inefficient management. At the same time, corporate governance is determined depending on the number of stakeholders taken into account in corporate relations. Thus, in the narrow sense, corporate governance is to ensure the activities of corporate managers in the interests of owners and shareholders. That is, corporate governance is seen as ways and means of guaranteeing all external financial investors (shareholders and creditors) a return on their investment. In a broad sense, corporate governance - taking into account and protecting the interests of both financial and non-financial investors (staff of the company, suppliers, local authorities, etc.), the state as a regulator of corporate relations, company owners (shareholders), their managers and all other employees in the process of achieving corporate goals.

Quite close to this definition is the interpretation of corporate governance as "establishing a balance of interests of different groups of stakeholders (shareholders, including large and minority, holders of preferred shares, government agencies, management)" [66]. Yu. Vynslav notes the traditional nature of this definition [67]. 
Approach to the definition of corporate governance as corporate rights management. Yevtushevsky V. considers corporate governance as management of corporate rights [68] In this case, corporate rights in a broad sense are the right of ownership of a share (share) in the statutory fund (capital) of a legal entity, including the right to manage assets in case of its liquidation in accordance with current legislation. Thus, considering corporate rights as the most common object of corporate governance, we can describe such management as the process of regulating the owner of the movement of his corporate rights for profit, corporate governance, reimbursement of expenses by obtaining a share of property in its liquidation, possible speculative transactions with corporate rights [68].

The subjects of corporate governance are the direct owners of corporate rights (citizens, legal entities, the state), the owners and management of an individual enterprise - the issuer of corporate rights or their owner.

More succinctly, corporate governance is a system of relations between the company's bodies and its owners (shareholders) regarding the management of the company's activities.

An approach to defining corporate governance as a system of relations. Corporate governance as a system of relations between shareholders, management bodies of a joint-stock company, its managers, as well as other stakeholders (employees, suppliers, consumers, creditors, state and local authorities, the public, etc.) to ensure the effective operation of the company stakeholders "is defined in the Concept of Corporate Governance Development in Ukraine.

Stakeholders mean persons who have a legitimate interest in the activities of the company, ie to some extent depend on the company or may influence its activities. Stakeholders include primarily employees (both those who are shareholders of the company and those who are not its shareholders), creditors, consumers of the company's products, the territorial community in which the company is located, as well as relevant government agencies and bodies. local government [69].

This approach should include the definition of the Organization for Economic Cooperation and Development (OECD unites 29 countries with developed market economies): "Corporate governance is the internal means of ensuring the activities of corporations and control over them ... One of the key elements of economic efficiency is corporate governance, which includes a set of relations between the board (management, administration) of the company, its board of directors (supervisory board), shareholders and other stakeholders (stakeholders). Corporate governance also determines the mechanisms by which the company's goals are formulated, the means of their achievement and control over its activities are determined "[70]. 
In order to determine the corporate governance rating, Standard \& Poor's defines "corporate governance as the interaction between managers, directors and shareholders in order to manage and control the company, as well as to obtain by all financial stakeholders their shares in the company's revenues and in its assets "[71].

An approach to defining corporate governance as a system that provides shareholder control over the company. A good corporate governance system allows investors to be confident that their investments are used effectively by the company's management in financial and economic activities and, thus, increases the value of investors' share in the company's share capital.

The approach in terms of management psychology defines corporate governance as management that generates corporate culture, ie a set of general traditions, attitudes, principles of behavior of participants in corporate relations.

An approach to the definition of corporate governance as the management of an integration association. For example, by definition of Khrabrova I. [72], "corporate governance is the management of organizational and legal design of business, optimization of organizational structures, building within the company's inter-firm relations in accordance with the accepted goals." S. Karnaukhov defines corporate governance as "management of a certain set of synergetic effects." Yu. Vinslav characterizes corporate governance as a system of management relations between interacting economic entities (including managers and subordinates) regarding the subordination and harmonization of their interests, ensuring synergy of both their joint activities and their relations with external counterparties (including government agencies). achieving the set goals "[73].

An approach to the definition of corporate governance as a set of norms, rules and processes of the regulatory mechanism. According to the World Bank, corporate governance combines the rules, regulations and practices of the private sector, which allows the company to attract financial and human resources, to conduct business efficiently and thus continue to operate, accumulating long-term economic value by increasing the value of shares and taking into account the interests of all persons involved in the management of the company (participants in corporate relations) and society as a whole. These persons of the company include: shareholders, creditors, employees, suppliers, customers, the local community as a whole, and others affected by the company's activities [74].

According to the CFA Financial Markets Integration Center, corporate governance is a system of internal control and management procedures of an individual company. It provides a structure that defines the rights, role and responsibilities of the various stakeholders within the organization. Corporate governance is the regulation of constraints, balance of influence, balance of interests 
and initiatives that companies need to minimize and manage conflicts of interest between insiders and external shareholders [75].

Povazhnii O. joins this approach: "The process of corporate governance is a set of processes of regulating the interests of participating groups and managing the corporation as an organization (involves managing its main resources, which include production, marketing, finance, personnel and R\&D)" [76-77].

Approach to the definition of corporate governance as a system of elected and appointed bodies. Referring to world practice, this approach is supported by Rumyantsev SA, defining corporate governance as a system of elected and appointed bodies that manage the activities of public companies, which reflects the balance of interests of owners and aims to ensure the maximum possible profit from all activities of the company. with the norms of current legislation [78].

Research has shown that corporate governance is a special type of management, the object of which is a joint stock company. The essence of corporate governance is determined by the specifics of the object of management. In this study, a joint stock company is understood as a set of special investments of human and physical capital.

According to $\mathrm{Yu}$. Vinslav, the subject of corporate governance is the organizational and managerial relations concerning the formation and use of share capital (property), as well as given that modern joint-stock companies have other legal entities, relations concerning the effective organization and coordination of actions, which are in contact with each other, as well as with the external environment [67].

Momot T. proposes to define "corporate governance" as a comprehensive system of internal and external mechanisms aimed at optimizing the structure of corporate relations to ensure harmonization of interests of all subjects of corporate relations and the implementation of an effective investment process in a joint stock company to maximize its capitalization [46].

We believe that "corporate governance" is a modern, progressive type of management within the economic system, which is characterized by a corporate strategy, corporate style of managers at all levels, corporate culture, financial and information openness, protection of shareholders and owners of other securities the issuing company [79].

One of the fundamental aspects of defining the principles and mechanisms for improving the effectiveness of corporate governance is to understand its essential content. An overview of approaches to the interpretation of the essence of corporate governance allows us to state the existence of at least seven approaches to the interpretation of this definition (Table 1). 


\section{Table 1. Basic approaches to the definition of "Corporate Governance"}

\begin{tabular}{|l|l|}
\hline \multicolumn{1}{|c|}{ Approach } & \multicolumn{1}{|c|}{ The concept of "corporate governance" } \\
\hline Regulatory and legal & $\begin{array}{l}\text { A system of legislation, regulations and business practices in the private } \\
\text { sector that allows a company to conduct business and continue to operate, } \\
\text { accumulating long-term economic value by increasing the value of shares }\end{array}$ \\
\hline $\begin{array}{l}\text { Organizational and } \\
\text { legal }\end{array}$ & $\begin{array}{l}\text { Management of organizational and legal registration of business, } \\
\text { optimization of organizational structures, construction of internal and } \\
\text { interfirm relations of the company according to the accepted purposes }\end{array}$ \\
\hline Relational & $\begin{array}{l}\text { The system of relationships between investors, owners, managers and } \\
\text { stakeholders to ensure the effective operation of the company, the balance } \\
\text { of interests of participants in corporate relations }\end{array}$ \\
\hline Administrative & $\begin{array}{l}\text { Management of corporate culture, ie a set of general traditions and } \\
\text { attitudes, the principles of the company's behavior in relation to its main } \\
\text { subsystems and elements, as well as in relation to society }\end{array}$ \\
\hline $\begin{array}{l}\text { Organizational and } \\
\text { managerial }\end{array}$ & $\begin{array}{l}\text { The system of bodies, positions, mechanisms and functions that exercise } \\
\text { regulatory influence on the company's activities }\end{array}$ \\
\hline Financial & $\begin{array}{l}\text { A system of bodies and mechanisms of managerial influence, which } \\
\text { ensures continuous optimal movement of financial flows of the company }\end{array}$ \\
\hline Financial and property & $\begin{array}{l}\text { The chosen method of self-government, which ensures fair and equal } \\
\text { distribution of performance between all shareholders, as well as } \\
\text { "financially interested persons, primarily creditors and investors" }\end{array}$ \\
\hline
\end{tabular}

Source: compiled by the authors based on materials [80-82]

Such a variety of approaches to understanding the essence of corporate governance leads to a multifaceted assessment of its effectiveness. Note that the effectiveness of corporate governance should be considered in three areas:

1) legal support of the rights of the company's owners, their interests and powers regarding the formation and management of property;

2) economic, legal and mental component of the formation of the mechanism of corporate governance;

3 ) ensuring the effectiveness of the developed corporate governance system and increase its efficiency.

In the developed world there are different models of corporate governance. The corporate governance model is a reflection of the most significant characteristics, properties and patterns of corporate governance as an object of socio-economic reality, created by the researcher to gain new knowledge about the corporate governance system in accordance with the purpose of the study [83]. Experts distinguish three models of corporate governance: Anglo-American, Japanese and German.

The Anglo-American model (used in corporations in the UK, US, Australia, New Zealand, Canada and some other countries) is characterized by the presence of individual and institutional investors and the number of independent (growing) shareholders. "external" or "outsiders"), as well as a well-developed legal framework 
that defines the rights and responsibilities of three key players - the board of directors, managers and shareholders [84].

The Japanese model is based on close ties with a key bank and financial and industrial network (keiretsu). The Bank provides its corporate clients with loans and services for issuing securities, maintaining current accounts, and consulting services. This bank is often the main internal shareholder of the company. Independent shareholders are virtually unable to influence the firm's policy, so their number is quite small [84].

The German model is based on the banking system (banks act as creditors, voting agents, depositories), shareholders and employees [83]. The German model has three unique features that distinguish it from other models: bicameral board, consisting of executive and supervisory (supervisory) boards; legal restrictions on shareholders' voting rights, ie the company's charter limits the number of votes a shareholder has at the meeting, which may not coincide with the number of shares he owns [83].

The purpose of corporate governance according to the classic version is to protect participants in corporate relations from inefficient activities of hired managers. According to the definition of Lozgacheva TM, the purpose of corporate governance depends on the degree of involvement in the sphere of corporate relations of certain categories of potential participants [85]. The degree of involvement of participants through corporate governance is largely determined by economic, legal, historical and ethical norms and traditions.

The analysis showed that the main goals of corporate governance are: increasing the level of competitiveness based on creative self-realization of the executive body of the company and staff, ensuring the integrated use of available resources, coordination of social partnership, comprehensive focus on the consumer.

At the same time, given that the main interest of effective owners of a joint stock company is the maximum possible increase in the value of the company, the main purpose of corporate governance should be defined as strategic management of the value of the company in the interests of its owners by minimizing threats.

The global financial crisis may be a significant impetus for the introduction of corporate governance standards in Ukrainian companies. As a rule, difficult economic conditions can not only hinder the successful development of companies, but also create the conditions for finding ways to improve or radically change the principles of public administration and management practices of real business. One of the reasons for the global economic downturn, analysts recognize unreasonable financial decisions of investors, which led to significant losses of national and private capital. Most experts believe that corporate governance should become an effective mechanism for ensuring the interests of owners and investors, the introduction of a 
new management logic, which is based on approaches to prioritizing the welfare of company owners.

The above problems determine the impact of corporate governance on the economic security of construction companies and their economic activities in general, which necessitates the construction of a modern Ukrainian model of corporate governance, which would become a subsystem of the economic security of such enterprises.

We propose to consider the system of economic security of enterprises in the construction industry in the implementation of corporate governance as a system that has the following components (Fig. 1).

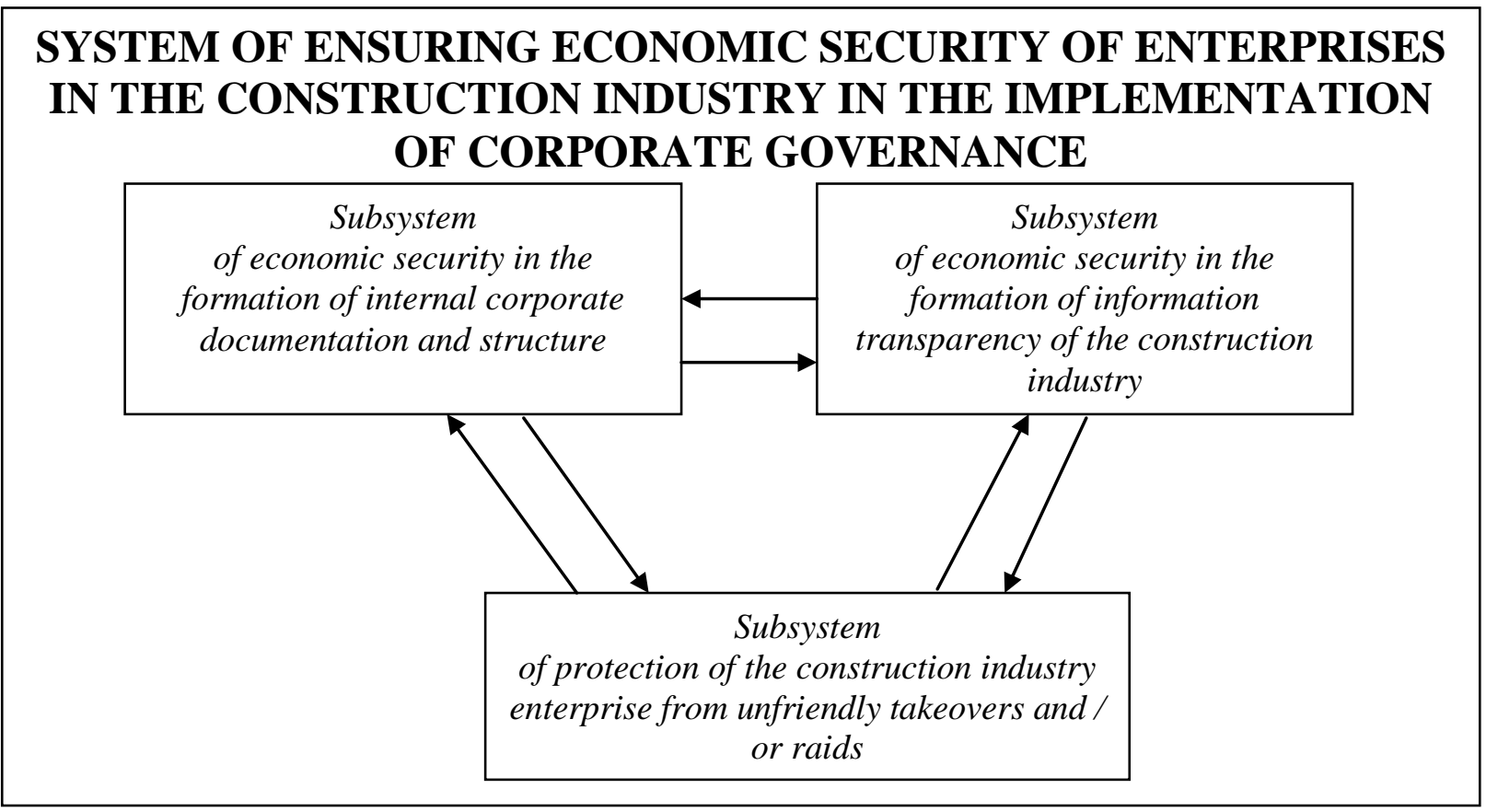

Fig. 1. Model of the system of economic security of enterprises of the construction industry in the implementation of corporate governance Source: compiled personally by the author

The author proposes that the main elements of the system of economic security of construction companies in the implementation of corporate governance include the following: objects, entities, regulatory and legal support of corporate governance, information support, threats, methodology for assessing the state of corporate governance (Fig. 2). 
The main elements of the system of economic security

of construction companies in the implementation of

corporate governance

\section{Objects of corporate governance}

- protection of shareholders' rights;

-public company status

\section{Subjects of corporate governance}

- shareholders;

-executive body (Board);

- supervisory body (Supervisory Board);

- corporate secretary

\section{Regulatory and legal support of corporate governance,}

- Constitution of Ukraine

-Laws of Ukraine;

- Principles of corporate governance;

-internal regulations and instructions

\section{Information support of corporate governance}

-regular information (annual report of the issuer and quarterly reports submitted to the SSMSC)

-special information (change of officials of the issuer, issue of shares, bankruptcy proceedings, etc.)

-information from the corporate site

Methodology for assessing the state of corporate governance

as an indicator of non-financial threats to the economic

security of the company

- assessment of corporate governance by individual indicators (assessment of the organization and holding of the general meeting of shareholders; assessment of the work of the supervisory board of the JSC; distribution of functions between the governing bodies of the JSC; availability of internal documents governing corporate governance; internal and external audits);

-monitoring the disclosure of information about the activities of the JSC (level of information transparency);

- comprehensive assessment of the state of corporate governance of the JSC (corporate governance rating)

Fig. 2. The main elements of the system of economic security of enterprises in the construction industry in the implementation of corporate governance Source: compiled personally by the authors 
Objects of corporate governance are:

- protection of shareholders' rights to receive information on the activities of construction companies, to receive dividends, to manage its activities, to decide on additional issues of shares and their acquisition, etc .;

- acquisition and maintenance of public company status.

The subjects of corporate governance are [86]:

- shareholders;

- executive body of the JSC (Management Board);

- supervisory body of the JSC (Supervisory Board);

- corporate secretary.

Regulatory and legal support of corporate governance in Ukraine is:

- Constitution of Ukraine [87];

- Laws of Ukraine "On Business Associations" [88], "On Joint Stock Companies" [89], "On Securities and Stock Market" [90], etc.);

- Principles of corporate governance [91], which are implemented in Ukraine or operate in those jurisdictions where the company plans to issue and publicly place shares;

- internal regulations and instructions adopted by the joint-stock company in accordance with the legislation of Ukraine and the Principles of Corporate Governance.

In accordance with the legislation of Ukraine and the practice of joint-stock companies, information management of corporate governance is [92]:

1) regular information (annual report of the issuer and quarterly reports submitted to the SSMSC);

2) special information (change of officials of the issuer, issue of shares, bankruptcy proceedings, etc.);

3) information from the corporate website, which discloses additional information on the state of corporate governance (minutes of the general meeting of shareholders, prospectuses of securities issues, exchange rates of the issuer's securities on stock exchanges, etc.).

Thus, information support of corporate governance combines the rules of law, regulations and takes into account the practice of management in the corporate sector, which allows the company to attract financial and human resources, effectively conduct business and continue to operate, increase the value of shares and respect the interests of all subjects of corporate relations. Thus, the system of corporate governance includes a set of legal and socio-behavioral norms and rules within which the company operates and on the basis of which the relationship between its members. 
Today in the world there are a large number of standards (principles, recommendations, codes) in the field of corporate governance at the international and national levels, as well as at the level of individual companies. Among them, the most authoritative are the Principles of Corporate Governance of the Organization for Economic Cooperation and Development (OECD), which were developed in 1999 on the basis of appeals from a number of international organizations and 22 developed countries, including the G7.

The OECD Principles define the main aspects of good corporate governance, namely [70]:

1. Shareholders' rights (the corporate governance system must protect the rights of shareholders).

2. Equal treatment of shareholders (the corporate governance system must ensure equal treatment of all shareholders, including minority and foreign shareholders).

3. The role of stakeholders in corporate governance (corporate governance system should recognize the statutory rights of stakeholders and encourage active cooperation between the company and all stakeholders to increase public wealth, create new jobs and achieve financial stability of the corporate sector).

4. Disclosure and transparency (corporate governance system should ensure timely disclosure of reliable information about all significant aspects of the corporation's operation, including information on the financial position, results of operations, composition of owners and management structure). It should be noted that these principles are of general importance, create a "global" vision of the components of effective corporate governance and should be combined with the specifics of a particular country and best practices in the private sector.

The main threats to the economic security of construction companies arising from inefficient corporate governance are:

1) the presence of corporate conflicts between shareholders, between shareholders and the company's management, between majority (large) and minority (small) shareholders;

2) unregulated internal provisions;

3) hostile (unfriendly) takeover and raider capture;

4) change in the share of authorized capital of minority shareholders due to small additional issues of shares;

5) untimely disclosure of information about the activities of the JSC, etc.

The authors argue that the methodology for assessing the state of corporate governance as an indicator of non-financial threats to the economic security of enterprises in the construction industry currently includes: assessment of corporate governance on individual indicators; monitoring the disclosure of information about 
the activities of joint stock companies and determining the level of their information transparency.

At present, unfortunately, there is no comprehensive assessment of the state of corporate governance of construction companies, which would use an integrated indicator (corporate governance rating) to reflect the impact of non-financial threats on the economic security of the company in the issuance and placement of its securities.

Therefore, best corporate governance practices should ensure that:

- members of the supervisory board act in the best interests of shareholders;

- the joint-stock company acts legally and ethically in relation to shareholders and their representatives;

- all shareholders have the same rights to participate in the management of the company and the fair consideration of cases by the supervisory board and board, all the rights of shareholders and other stakeholders are clearly described and brought to their notice;

- the supervisory board and its committees are structured to operate independently of the board, individuals and organizations that control the board and other non-shareholder groups;

- appropriate control and procedures accompany the daily operational work of the board;

- shareholders learn about the operational, financial and management activities of the joint-stock company from clear, accurate and timely reports that fully characterize the actual state of affairs.

The above confirms the place and importance of corporate governance in the system of economic security of construction companies and requires its inclusion as a separate subsystem.

\section{References:}

1. Momot, T. V. and Chalyi, I. H. (2005), "Corporate governance: modern conceptual approaches", Ekonomika i rehion. Naukovyi visnyk Poltavskoho natsionalnoho universytetu imeni Yuriia Kondratiuka, №3(6), pp. 47-50.

2. Berle, A. A. and Means, G. C. (1932), "The Modern Corporation and Private Property", New York, pp. 172.

3. Druker, P. F. (2000), Zadachy menedzhmenta v KhKhI veke [Management tasks in the XXI century], Vyliams, Moscow, Russia, 272 p.

4. Keins, D. M. (1993), Yzbrannie proyzvedenyia [Selected works], Tsentr ekonomyki i marketynha, Moscow, Russia.

5. Marshall, A. (1993), Pryntsypi ekonomycheskoi teorii [Principles of economic theory], Progress, Moscow, Russia, Part 3, 351 p.

6. Marshall, A. (1993), Pryntsypi ekonomycheskoi teorii [Principles of economic theory], Progress, Moscow, Russia, Part 2, 310 p.

7. Porter, M. E. (1998), Stratehiia konkurentsii [Competition strategy], Osnovi, Kyiv, Ukraine, 390 p.

8. Samuelson, P. E. and Nordkhaus, V. D. (2003), Ekonomika [Economics], Vyliams, Moscow, Russia, 680 p. 
9. Chemberlyn, E. (1996), Teoryia monopolystycheskoi konkurentsyy: Reoryentatsyia teoryy stoymosty [Theory of monopolistic competition: Reorientation of the theory of value], Ekonomika, Moscow, Russia, $351 \mathrm{p}$.

10.Akoff, R. (1985), Planyrovanye budushcheho korporatsyy [Planning for the future of the corporation], Prohress, Moscow, Russia, 327 p.

11.Harvard Business Review on Corporate Governance (2000), Boston (Ma., USA): Harvard Business School Press, $217 \mathrm{p}$.

12.Monks, R. and Minow, N. (2004), Corporate Governance, 3rd Edition, Oxford: Blackwell Publishers Ltd., 539 p.

13.Monks, R. and Minow, N. (1996), Watching the Watchers: Corporate Governance for the 21st Century, Oxford: Blackwell Publishers Ltd., 331 p.

14.Radihin, A. (2004), "Corporate governance: limitations, contradictions and features of regulation", Problemi teorii i praktiki upravleniia, №2, pp. 91-97.

15.Stewart, G. B. (1991), The Quest for Value - The EVA Management Guide, NY, 46 p.

16.Sheyn, V. Y. Zhuplev, A. V. and Volodyn, A. A. (2000), Korporatyvnii menedzhment: opit Rossii i SShA [Corporate management: the experience of Russia and the United States], OAO «Typohrafyia «Novosty», Moscow, Russia, 280 p.

17.Voronkova, A. E. (2004), Strategicheskoe upravlenie konkurentosposobny`m potenczialom predpriyatiya: diagnostika i organizacziya [Strategic management of the competitive potential of the enterprise: diagnostics and organization], Vostochnoukrainskij naczionalnij universitet, Lugansk, $315 \mathrm{p}$.

18.Yevtushevskij, V. A. (2002), Osnovy korporatyvnoho upravlinnia [Fundamentals of corporate governance], Znannia-Pres, Kyiv, Ukraine, 317 p.

19.Kozachenko, G. V. (2003), "Strategic management of corporations”, Naukovyi visnyk NHU, № 3, pp. 4449.

20.Kuzmin, O. Ye. Moroz, A. S. Podolchak, N. Yu. and Shuliar, R. V. (2005), Transformatsiia pidpryiemstv: ekonomichna otsinka ta pobudova system menedzhmentu [Transformation of enterprises: economic evaluation and construction of management systems], Lvivska politekhnika, Lviv, Ukraine, 335 p.

21.Nazarova, H. V. (2004), Orhanizatsiini struktury upravlinnia korporatsiiamy [Organizational structures of corporate governance], VD «INZhEK», Kharkiv, Ukraine, $420 \mathrm{p}$.

22.Nazarova, H. V. (2002), "System of international corporate governance standards", Finansy Ukrainy, №10, pp. 67-74.

23.Palyha, Ye. (2003), "Corporate governance as a way to ensure the economic security of the enterprise", Rehionalna ekonomika, № 2, pp. 106-109.

24.Achkasov, A. E. (1998), "On one model for choosing a system of technical and economic indicators", Kommunalnoe hozyaystvo gorodov, № 9, pp. 116-122.

25.Blank, I. A. (1999), "Fundamentals of financial management", Byblyoteka fynansovoho menedzhmenta, part. $1,592 \mathrm{p}$.

26.Vakulchyk, O. M. (2003), Korporatyvne upravlinnia: ekonomiko-analitychnyi aspect [Corporate governance: economical and analytical aspect], Porohy, Dnipropetrovsk, $257 \mathrm{p}$.

27.Volynskyi, H. S. (2006), "Synergy as a component of assessing the effectiveness of the implementation of quality corporate governance of a construction joint-stock company", Ekonomika: problemy teorii ta praktyky, №217, part 1, pp. 95-101.

28. Volynskyi, H. S. (2004), "Post-privatization period of development of the construction industry: the aspect of pricing", Kommunalnoe hozyaystvo gorodov, vol. 59, pp. 60-63.

29. Volyinskiy, G. S. (2006), "The quality of corporate governance as a factor in increasing the capitalization of a joint stock company”, Biznes-Inform, № 6, pp. 117-121.

30. Ivanilov, O. S. (2000), Ekonomika budivnytstva [Construction economics], Vyshcha shkola, Kharkiv, Ukraine, $584 \mathrm{p}$.

31.Lushkyn, V. A. Berezhnaia, A. Iu. and Achkasov, A. E. (2001), Finansyi. Dengi. Kredit [Finance. Money. Credit], HGAGH, Kharkiv, Ukraine, 330 p.

32. CHumachenko, N. G. CHervova, L. G. and Kuzmenko, L. M. (2002), Regionalnaya promyishlennaya politika: kontseptsii formirovaniya $i$ realizatsii [Regional industrial policy: concepts of formation and implementation], IEP, Donetsk, Ukraine, 303 p.

33.Mendrul, O. H. (2003), "Enterprise value management: theoretical and practical aspects", Doctor of sciences thesis, Economics, Kyiv National University of Economics, Kyiv, 24 p.

34.Chechetov, M. and Mendrul, O. (2001), "Corporate governance in the conditions of economic transformation”, Ekonomika Ukrainy, № 4, pp. 10-18. 
35.Tian, R. B. and Zalunyn, V. F. (1997), "Problems of the cost of construction projects", Upravlenie stroitelnyimi proektami, part 2, pp. 73-76.

36. Anin, V. I. (2003), "Forecasting economic indicators", Formuvannia rynkovykh vidnosyn v Ukraini, №78, pp. 133-137.

37.Krushevskyi, A. V. (2001), Matematychne prohramuvannia dlia ekonomistiv ta menedzheriv [Mathematical programming for economists and managers], UMMO, Kyiv, Ukraine, $101 \mathrm{p}$.

38. Krushevskyi, A. V. (200), Systemne doslidzhennia finansovo- ekonomichnykh obiektiv [Systematic study of financial and economic objects], Sammyt-knyha, Kyiv, Ukraine, 70 p.

39.Krushevskyi, A. V. (2001), "A systematic approach to the study of economic efficiency of investments", Budivelne vyrobnytstvo, №42, pp. 72-74.

40.Onyshchenko, V. O. (2006), "The influence of corporate governance on the entry of joint-stock companies in the construction industry on the civilized capital market", Kultura narodov Prychornomoria, № 83, pp. 12-14.

41.Povajnyiy, A. S. (2001), "The concept of "corporate governance": analysis of different approaches", Ekonomika: problemy teorii ta praktyky, № 99, pp. 29-35.

42.Povajnyiy, A. S. (2002), Problemyi upravleniya i organizatsii deyatelnosti aktsionernyih obschestv $v$ Ukraine [Problems of management and organization of activities of joint stock companies in Ukraine], NANU YЭP, Donetsk, Ukraine, 298 p.

43.Torkatiuk, V. Y. Mariukhyn, V. N. and Denysenko, A. P. (2001), "Economic problems of management in the construction industry of Ukraine", Radioelektronika i molodej v XX veke [Radio electronics and youth in the twentieth century], 5-y mezhdunarodnii molodezhnii forum [5th international youth forum], KhTURE, Kharkiv, Ukraine, pp. 402-406.

44.Torkatyuk, V. I. Momot, T. V. and Bordun, A. M. (2001), "Regulation of the securities market of the Kharkiv region: problems and development prospects", Suchasni problemy humanizatsii ta harmonizatsii upravlinnia [Modern problems of humanization and harmonization of management], Materialy 2-yi mizhnarodnoi mizhdystsyplinarnoi naukovo-praktychnoi konferentsi [Proceedings of the 2nd International Interdisciplinary Scientific and Practical Conference], Kharkivskyi natsionalnyi universytet imeni V.N. Karazina, Kharkiv, Ukraine, pp. 101-102.

45.Torkatiuk, V. I. and Momot, T. V. (2002), "Problems of corporate governance development in Ukraine", Tezisyi dokladov XXXI nauchno-tehnicheskoy konferentsii prepodavateley, aspirantov $i$ sotrudnikov Harkovskoy gosudarstvennoy akademii gorodskogo hozyaystva [Abstracts of the XXXI scientific and technical conference of teachers, graduate students and employees of the Kharkov State Academy of Urban Economy], Kharkiv, Ukraine, pp. 35-36.

46.Torkatiuk, V. I. Momot, T. V. and Soboleva, A. H. (2003), "Analysis of the functioning of closed joint stock companies: the experience of Ukraine and Russia", Kommunalnoe hozyaystvo gorodov. Seriya: Ekonomicheskie nauki, №48, pp. 154-158.

47.Fedorenko, V. H. Stepanov, D. V. Chuvadynskyi, O. H. And other (2003), Shliakhy pidvyshchennia investytsiinoi diialnosti v Ukraini [Ways to increase investment activity in Ukraine], Aspekt-Polihraf, Kyiv, Ukraine, $723 \mathrm{p}$.

48.Ushatskyi, S. A. Lahutin, H. V. Pokolenko, V. O. and Shpakov, A.V. (2003), Finansovo-budivelni hrupy: novi uchasnyky investytsiinoho protsesu [Financial and construction groups: new participants in the investment process], KNUBA, Kyiv, Ukraine, 111 p.

49.Ushatskyi, S. A. And other (2003), Shliakhy pidvyshchennia efektyvnosti budivnytstva $v$ umovakh formuvannia rynkovykh vidnosyn [Ways to increase the efficiency of construction in the formation of market relations], KNUBA, Kyiv, Ukraine, 183 p.

50.Fedosova, E. V. (1988), Industrialnyie stroitelno-tehnologicheskie sistemyi - uskoriteli nauchnotehnicheskogo progressa [Industrial building and technological systems are accelerators of scientific and technological progress], Vyshcha shkola, Kyiv, Ukraine, 166 p.

51.Mikhels, V. O. and Bondar, V. P. (2003), Obiednana stratehiia ekonomichnoho upravlinnia pidpryiemnytskym proektom [Joint strategy of economic management of business project], KNUBA, Kyiv, Ukraine, $200 \mathrm{p}$.

52.Nalyvaiko, A. P. (2001), Teoriia stratehii pidpryiemstva. Suchasnyi stan ta napriamky rozvytku [Theory of enterprise strategy. Current state and directions of development], KNEU, Kyiv, Ukraine, $227 \mathrm{p}$.

53.Tischenko, A. N. and Golovko, O. S. (2003), Strategiya upravleniya razvitiem predpriyatiya [Enterprise development management strategy], EDENA, Kharkiv, Ukraine, 198 p.

54.Shevchenko, L. S. (2004), Konkurentnoe upravlenie [Competitive governance], Espada, Kharkiv, Ukraine, $520 \mathrm{p}$. 
55.Shutenko, L. N. (2002), Tehnologicheskie osnovyi formirovaniya i optimizatsii jiznennogo tsikla gorodskogo jilogo fonda [Technological foundations for the formation and optimization of the life cycle of the urban housing stock], Maidan, Kharkiv, Ukraine, $1054 \mathrm{p}$.

56.Shutenko, L. N. Torkatiuk, V. Y. Pan, N. P. Zolotova, N. M. and Butnyk, S. V. (2003), "The main directions of improving strategic management at construction enterprises", Kommunalnoe hozyaystvo gorodov, №51, pp. 29-56.

57.Scherbakova, O. N. (2003), "Methods for assessing and managing company value based on the concept of economic added value", $F M$, №3, pp. 46-54.

58.Bubenko, S. P. (2002), "Organizational and economic mechanism of export activity of the enterprise", Finansy Ukrainy, № 10, pp. 75-78.

59.Holikov, A. P. (2001), "Ukraine's regional policy on the way to European integration", Sotsialnoekonomichni doslidzhennia u perekhidnyi period. Problemy yevropeiskoi intehratsii $i$ transkordonnoi spivpratsi, pp. 146-151.

60.Holikov, A. P. Bakirov, V. S. and Lohvinenko, O. S. (2001), Rehionalna polityka na suchasnomu etapi rozvytku Ukrainy [Regional policy at the present stage of Ukraine's development], NDI, Kharkiv, Ukraine.

61.Kovalevskyi, H. V. (1978), "System analysis - a system of methods", Vestnik statistiki, №2, pp. 35-43.

62.Kovalevskyi, H. V. and Kazak, T. V. (2001), "New concept, model and program of systemic development of the region (on the example of the Kharkiv region)", Kommunalnoe hozyaystvo gorodov, №34, pp. 3-8.

63.Kovalevskyi, H. V. and Selivanov, V. M. (2004), Kharkivska ekonomichna shkola 1804-2004 [Kharkiv economic school (1804-2004)], KhNU, Kharkiv, Ukraine, 45 p.

64.Nikolaev, V. P. Orlovskih, YU. V. and Chumakova, E. G. (2003), Problemyi reytingovoy otsenki investitsionnoy privlekatelnosti: vnutriregionalnyiy aspekt [Problems of rating assessment of investment attractiveness: intraregional aspect], Nauka i obrazovanie, Dnipropetrovsk, Ukraine, 100 p.

65.Onyshchuk, H. I. (2001), "Improving corporate governance of territorial entities", Stratehiia ekonomichnoho rozvytku Ukrainy, №7, pp. 592-601.

66. Varnalii, Z. S. and Sergienko, O. V. (1999), Male pidpryiemnytstvo $v$ krainakh z perekhidnoiu ekonomikoiu (problemy derzhavnoi pidtrymky) [Small business in countries with economies in transition (problems of state support)], Znannia, Kyiv, Ukraine, 11 p.

67.Vynslav, Yu. (2001), "Formation of domestic corporate governance: theory, practice, approaches to solving key problems", Rossiyskiy ekonomicheskiy jurnal, № 2, pp. 15-28.

68.Ievtushevskyi, V. A. (2002), Osnovy korporatyvnoho upravlinnia [Fundamentals of corporate governance], Znannia-Pres, Kyiv, Ukraine, 317 p.

69.Panasiuk, N. O. (2004), "Principles of corporate governance”, Ukrainska investytsiina hazeta, №4, pp. 38.

70.Principles OECD of Corporate Governance (202). URL

http://www.oecd.org/daf/governance/principleshtm.

71.Agency Standard \& Poor's (2020). URL : www.standardandpoors.ru.

72.Khrabrova, Y. A. (2000), Korporatyvnoe upravlenye: voprosi yntehratsyy. Affylyrovannie lytsa, orhanyzatsyonnoe proektyrovanye, yntehratsyonnaia dynamyka [Corporate governance: issues of integration. Affiliates, organizational design, integration dynamics], YNFRA, Moscow, Russia, 198 p.

73.Karnaukhov, S. (2000), "Efficiency of corporate structures", Rysk, №1.-2, pp. 4-8.

74.Pryhozhyn, A. Y. (1978), Posobye po provedenyiu tekhnyko-promishlennikh yssledovanyi [Manual for technical and industrial research], YuNYDO, Moscow, Ukraine, $156 \mathrm{p}$.

75.The Corporate Governance of Listed Companies: A Manual for Investors. CFA Institute: CFA Centre for Financial Market Integrity, 2005. 56 p.

76.Povazhnii, A. S. (2001), "The concept of "corporate governance": an analysis of different approaches", Ekonomika: problemi teoriï ta praktiki, № 99, pp. 29-35.

77.Povajnyiy, A. S. (2002), Problemyi upravleniya i organizatsii deyatelnosti aktsionernyih obschestv $v$ Ukraine [Problems of management and organization of joint-stock companies in Ukraine], NANU YEP, Donetsk, Ukraine, 298 p.

78.Rumiantsev, S. (2003), "Legal regulation of CJSC activity", Tsinni papery Ukrainy, № 18, pp. 12-18. 79.Mihus, I. P. Khudolii, L. M. Denysenko, M. P. and Mikhno, S. P. (2012), Korporatyvne upravlinnia v systemi ekonomichnoi bezpeky aktsionernykh tovarystv Ukrainy [Corporate governance in the system of economic security of joint-stock companies of Ukraine], TOV "Maklaut", Cherkasy, Ukraine, 274 p.

80.Dzheims, M. and Koller, T. (2000), "Emerging markets: features of company valuation", Vestnyk MakKynsy, № 4, pp. 7-11. 
81.Mikhels, V. O. and Bondar, V. P. (2003), Obiednana stratehiia ekonomichnoho upravlinnia pidpryiemnytskym proektom [Joint strategy of economic management of business project], KNUBA, Kyiv, Ukraine, $200 \mathrm{p}$.

82.Mohylevskyi, S. D. (2001), Orhani upravlenyia khoziaistvennimy obshchestvamy: Pravovoi aspekt [Management bodies of business companies: Legal aspect], Delo, Moscow, Russia, $360 \mathrm{p}$.

83.Krush, P. V. Kavtysh, O. P. Hrechko, A. V. and Chykhachova, Yu. S. (2007), Formuvannia modeli korporatyvnoho upravlinnia $v$ transformatsiinii ekonomitsi [Formation of a model of corporate governance in a transformational economy], TsUL, Kyiv, Ukraine, 264 p.

84.Dovhan, L. Ie. Pastukhova, V. V. and Savchuk, L. M. (2004), Upravlinnia korporatsiiamy [Corporate governance], Politekhnika, Kyiv, Ukraine, 236 p.

85.Lozghacheva, T. M. (2002), "Formation of the organizational mechanism of corporate governance", PhD Thesis, Economy, Nizhny Novgorod State University of Architecture and Civil Engineering, Nizhny Novgorod, Russia, $24 \mathrm{p}$.

86.Kurinnoi, Ye. I. and Vakulchyk, O. M. (2002), "Search for the criterion of production efficiency in the conditions of corporate relations", Derzhavnyi informatsiinyi biuleten pro pryvatyzatsiiu, № 12, pp. 45-49.

87.The Verkhovna Rada of Ukraine (2003), The Law of Ukraine "The Constitution of Ukraine". URL : https://zakon.rada.gov.ua/laws/show/254\%D0\%BA/96-\%D0\%B2\%D1\%80\#Text.

88. The Verkhovna Rada of Ukraine (1991), The Law of Ukraine "About business associations". URL : https://zakon.rada.gov.ua/laws/show/1576-12\#Text.

89.The Verkhovna Rada of Ukraine (2011), The Law of Ukraine “About joint-stock companies”. URL : https://zakon.rada.gov.ua/laws/show/514-17\#Text.

90.The Verkhovna Rada of Ukraine (2006), The Law of Ukraine "On securities and the stock market". URL : https://zakon.rada.gov.ua/laws/show/3480-15\#Text.

91.The Verkhovna Rada of Ukraine (2003), The Law of Ukraine "On approval of the Principles of corporate governance: Decision of the State Commission on Securities and Stock Market". URL : https://zakon.rada.gov.ua/rada/show/vr955863-14\#Text.

92. The Verkhovna Rada of Ukraine (1996), The Law of Ukraine "On approval of the Interim Regulations on the provision of regular and special information by open joint-stock companies and bond issuers". URL : https://zakon.rada.gov.ua/laws/show/z0431-98\#Text. 